\title{
Research Notes
}

\section{The Soviet Occupation of Afghanistan: Implications for Muslim Central Asia and the Muslim World}

\section{by Mushtaqur Rahman}

ISLAM is as natural to the people of Afghanistan as the air they breathe. Any system repugnant to Islam or the introduction of alien forces to introduce a new social order has always been resisted by the Afghans. The present Afghan-Soviet war is one such story.

The war is a matter of vital importance because its outcome will immensely affect Pakistan, Iran, and the rest of the Muslim world. It will also upset the balance of power between the West and the Soviets, and might change the direction of oil flow. It is curious that the war is not given the support or attention it deserves, in spite of its global ramifications. The West perhaps ignores the war as Afghanistan is far removed from the Western mainstream, and its impact is not generally understood because the Afghan Mujahideen lack a sophisticated network of information. Moreover, the Soviets continue misleading the world by claiming the war is only a law and order problem between the Afghan government and a handful of "bandits" encouraged from outside.

The war is neither a law and order matter nor its impact hard to realize. Afghan Mujahideen are fighting the Soviets to force them out of Afghanistan, and the Soviets are trying to hold on using biological, chemical, and other sophisticated weapons. In spite of enormous destruction and genocide, the Afghan Mujahideen are determined to fight to the last, and so apparently are the Soviets to consolidate their occupation of Afghanistan. This paper presents an analysis of the war and its impact on Pakistan, the Muslim world, and the West from a geopolitical standpoint. A brief discussion of Afghanistan explains the former status of Afghanistan as a buffer state first between the Russians and the British and later between the Soviets and Pakistan.

Modern Afghanistan dates back to 1747 when Ahmad Shah Durrani took over reins of that country. More or less during the same time, the British 
were establishing themselves in South Asia under the aegis of the East India Company. As mercentile interests developed into political involvements, the British continued to extend their control right up to the Afghanistan border.

From the other side, the Russians were engaged in taking over Central Asia and advancing towards Afghanistan during the first half of the 19th century. In 1865 they annexed Taskent, in 1867 Bokhara, in 1868 Samarkand, in 1875 Khokhand, and in 1900 extended their control over the Pamir.

The Pamir convention held in 1892 between the Russians and the British made the Wakhan Panhandle a part of Afganistan, so that the British and Russian forces might not face each other. The eastern and southern boundary popularly known as the Durrand Line was demarcated in 1893. The Durrand line now forms the boundary between Afghanistan and Pakistan. Pakistan's alignment with the Western defense system in the 1950's infuriated the Soviets, as demonstrated by their substantial aid to Afghanistan. With this aid, the Soviets encouraged Afghanistan to subvert Pakistan's interests in all possible ways and at all levels. With Soviet backing, Afghanistan challenged its boundary with Pakistan, demanding an independent state of "Pakhtunistan" covering the area where Pakhtuns are dominant in Pakistan. Relations between the two Muslim countries worsened and as a result the Pakistan-Afghanistan border was sealed a number of times. The Soviets took advantage of all such occasions and, in order to consolidate their hold, covered the whole country by a ring of exceedingly good roads as a means to provide alternate routes. These roads are Class A roads with strong bridges capable of withstanding tank loads. A tunnel (Salang tunnel) was also completed in 1964 piercing the Hindukush mountains to provide a direct link with the Soviet Union.

The United States started taking an interest in the economic development of Afghanistan in 1954, but it remained too insignificant to offset the growing Soviet influence. As a result, the first major jolt came in July 1973 when the monarchy was toppled by a former Prime Minister, Mohammad Daud Khan, who was also a cousin of the King. Mohammad Daud was killed in a Communist-led coup in April 1978. Then a popular uprising against the Communist government was so strong and and widespread that the Soviets decided to move in and occupy the country in order to save their puppet government in Kabul.

By December 1980, within one year of the Soviet occupation, as many as 1.3 million refugees were forced into Pakistan. The border districts and agencies were the first to receive these refugees, in which their number exceeded the local population. According to recent reports, more than 4.5 million refugees have been forced out of Afghanistan (about 3.5 million are in Pakistan and 1 million in Iran).

Since December 1979, the Afghan Mujahideen have been fighting the Soviets to force them out of their country. By any stretch of the imagination, 
their war is a matter of vital importance because its outcome will immensely affect Pakistan, the Middle East, and the rest of the world. It will upset the balance of power between the Soviets and the West and change the direction of oil flow. The war scenario becomes more serious because the Mujahideen seem determined to fight to the last to force the Soviets out of Afghanistan. The Mujahideen's determination is based on Islamic ideals, which clash with the Soviet ideology and interest. One of the basic reasons prompting the Soviets to occupy Afghanistan was to prevent an Islamic reawakening in other Islamic nations so close to their southern border, comprising the Muslim population of Central Asia under Soviet control.

This population-ethnic Uzbeks, Turkoman, Kazhaks, Tajiks, Khirgiz, and others have consistently resisted the Communist Party's attempts to dilute their Islamic identity. In spite of untold atrocities of the Soviets to implant their official atheistic policy, 90 to 95 percent of them still observe Muslim family rites and religion. ${ }^{1}$

The anti-Muslim Soviet policy can roughly be divided into six phases. ${ }^{2}$ During the first phase (1917-20), all Muslim endowments were confiscated, Maktabs were secularized, and Shariah courts were closed. The Second Phase (1921-27) began with a brief reprieve, followed by a more intense period of atrocities. In the early years, endowments were returned and Maktabs were reopened, due to strong Muslim protests and opposition, called by the Soviets the "Basmachi" movement.

But the endowments were again confiscated in 1925 and Maktab and Shariah courts were closed. Muslim laws were banned and Arabic script was made illegal. Even the publication of books in the Arabic language was disallowed.

The Third Phase (1928-41), also called the Stalin era, was the worst of all. Laws regulating Muslim marriage and divorce were banned, and mosques were confiscated and leased to the registered societies. Religious instruction was prohibited to children below the age of 18 years. Zakah, Haj, and Ramadhan were restricted. As a result, the number of mosques and Imams dropped considerably by 1929 , as in evident from the following table:

Number of Mosques and Imams in Muslim Central Asia, 1912-1929

\section{2}

Mosques

Imams
26,279

45,339
1929

1,312

8,052

\footnotetext{
' A Benningsen and M. Boxrup, The Islamic Threat to the Soviet Union (N.Y.: st Martin's, 1983), p. 1.

2 Mahammad Said, Central Asian Muslims, a lecture delivered at Iowa State University, October 22, 1986 (unpublished).
} 
The Fourth Phase (1941-53), marks a period of the Second World War when the Soviet army was losing against the Germans. Continued reversals and defeats in the early years of the war compelled the Soviets to seek active Muslim cooperation in their war effort. To appease the Muslims, they allowed reopening of a few mosques and Madrasas, allowed a small number of people to go on the hajj, and authorized publication of one religious magazine. They also established three "Spiritual Administration Centers," headquartered in Tashkent, Baku, and Ufa, to serve the Muslim interests. After the war, however, the Soviet policy changed again.

During the Fifth Phase (1954-64), the mosques were reduced from 3000 to 400 persons, and more than 200 books were published against Islam in 21 languages spoken by the people in Central Asia. More than 145,000 lectures against Islam were delivered in one year in Uzbekistan alone. ${ }^{3}$

The sixth and the final phase (1964-1980), during which Afghanistan was also occupied, is marked by continued aggression and anti-Muslim policy. Only for purposes of propaganda have the "Spiritual Administration Centers" been reopened and reorganized. Their added responsibility now is to keep track of Muslim activities in Central Asia, and project a Soviet image as a friend of Muslims to the outside world.

With time, the Muslims in Central Asia are becoming more insolent and violent, with little interest in the Communist ideology. Their insolence is exacerbated by their numbers, which is close to 55 million, or 20 percent of the total population of the Soviet Union. Given their growth rate, which is the highest in the Soviet Union, they will become one fourth of the total population by the year 2000 . Their young people of military draft age will constitute 29 percent of the total Red Army. As Soviet Muslims gain in numerical strength and relative population density, their recalcitrance, maintained for over 50 years, becomes potentially more troublesome for the Soviet system.

The Islamic resurgence of the Soviet Muslims has increased in recent years, because of some internal and external factors. Internally, the Sovietization policy, racial discrimination, and economic exploitation is making the Muslims more disillusioned. Economically, the Muslim areas contribute substantially to the Soviet resources but get very little in return.

Muslim Central Asia: Resources

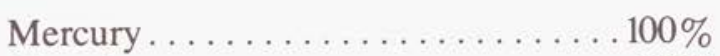

(of the Soviet Union)

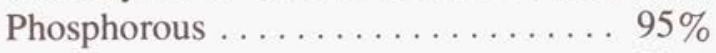

Uranium .............. $90 \%$ 


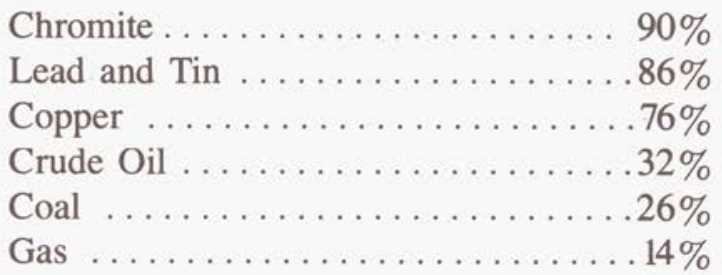

Externally, the emergence of Pakistan as an independent Muslim state, the economic prosperity of the Muslim world, the penetration of revolutionary ideas from Iran, and the resistence of the Mujahideen in Afghanistan are also important contributing factors. The Soviet press often reports that Islamic literature and cassette tapes in Russian and Uzbek languages penetrate into Soviet Asia. ${ }^{4}$ Because of the unwillingness of the Soviet Muslims to assimilate into the Soviet system and the potential influence from the restive population south of their border, the Soviets would cling to Afghanistan until forced out. They would not allow the Soviet Muslims to be encouraged by a Mujahideen victory by letting them establish an independent Islamic state in Afghanistan.

Instead of withdrawing from Afghanistan, there is a danger that the Soviets may occupy neighboring territories to extend their control to the Arabian Sea. The danger of further occupation is associated with improvements in the transport system of Central Asia and Afghanistan. Modern highways, airports, supply depots, and pipelines are being built that will effectively shorten the distances between places in this region and reduce the costs of social and economic interaction between Soviet Central Asia and Afghanistan, and, on a wider scale, between the Soviet Union and other nations of South and Southwest Asia. As a result, the economies of these nations and eventually their political interests can become progressively intertwined, and greater Central Asia can then become a strategic geopolitical center. ${ }^{5}$

Transport is also being modernized in Afghanistan, beyond what was constructed with the help of the Soviets and Americans in the 1960s. A modern bridge over the Oxus River between Termez (on the Soviet side) and Haritan (on the Afghanistan side) was completed in May 1983, connecting the highways of the Soviet Union to those of Afghanistan, which in turn are linked to the highways in Pakistan. ${ }^{6}$ It is now possible to travel on paved roads from Leningrad to Karachi, a distance of 2600 miles in less than 60 hours driving time. Besides the highways that have been modernized in Afghanistan, other transport and shipping facilities have been improved. The interlocking of the Soviet Union and Afghanistan's transport networks will change the cost-benefit struc-

\footnotetext{
" A. Benningsen "Supernational Identity: Pan-Turkism and Pan-Islamism in History and Today," Central Asian Survey, Vol. 3, No. 3, 1984.

5 J.D. Dawney, USSR in Maps (Holmes and Meir, 1982).

${ }^{6}$ R.S. Newell, The Politics of Afghanistan (Ithaca: Cornell University Press, 1972), p. 131.
} 
ture of their economic relations and indeed of economic and political relations in the entire region. A technologcal breakthrough of this kind has lasting social and political implications, although it may not be heralded as a political event.

The Soviet annexation of the Wakhan Panhandle in July 1981 is clearly another step in the same direction. The Wakhan Panhandle is 200 miles long and 5 to 50 miles wide, with an elevation ranging between 10,000 to 17,000 feet. Four passes link it with Pakistan, and two with the Soviet Union. The Soviets forced all its Muslim population out, and turned it into a military base. The Peking Review in August 1982 reported that,

more than 4000 Soviet troops are stationed in the Wakhan Panhandle. Many troops patrolling the passes leading to China and Pakistan have built underground bunkers, ground to ground missile sites, and widened the roads. A number of short range missiles of Frog 2 and Frog 3 together with An-12 "CAB" aircraft and other armaments have been reported from the area.

It seems that the Soviet boundary with Afghanistan demarcated and settled in 1921 was a temporary measure. They have extended it to Pakistan in 1979, and may now be waiting for an opportune moment to extend it further.

By annexing Wakhan, whose southernmost part is only 30 miles from the KK Highway which links Pakistan and China, the Soviets have secured the third of the three axis or approaches towards the Gulf and the Arabian Sea. These three approaches are:

1) via Merv-Khushka-Mazari Sharif-Gawadar

2) via Termez-Mazari Sharif-Kabul-Peshawar-Karachi/Port Qasim

3) via Badakshan-Margh-Wakhan-'Gilgit-KK Highway-Islamabad-

Karachi/Port Qasim

Pressure on the border areas is increasing without any international condemnation or consternation. Recent press reports are quite alarming. Pressure on the borders may continue to increase from the Soviet side in the Eighties and beyond. This scenario need not result from a self-conscious Soviet policy, for geography and technology exert a compelling influence on social affairs in their own right, and the Soviets happen in fact to be carrying out policies to hasten the process. Along with interlinking the Afghan economy with their own, the Soviets are believed to be planning to integrate Afhanistan into the Soviet Republics politically by redrawing the boundaries of some of the existing republics down to the Hindukush range and carving out a "Pukhtunistan 
Republic" in the south. ${ }^{7}$

It is ovious that the Mujahideen resistence is a major obstacle to the effective ingestion of Afghanistan by the Soviets. The Soviet-developed transportation network in Afghanistan cannot be maintained uninterrupted as long as the Mujahideen resistence is active and effective. It thus obstructs the expansion of Soviet influence into the wider region. Essentially concerned with protecting their homeland, the Mujahideen are defending the interests of a wide circle of other Muslim nations.

However great the stakes are for the Soviets in the Afghanistan war, the stakes for the Muslim world and the West are greater. They are wedded to the cause of the Afghan Mujahideen, who may be the last bulwark in Southwest Asia against an invading Soviet presence.

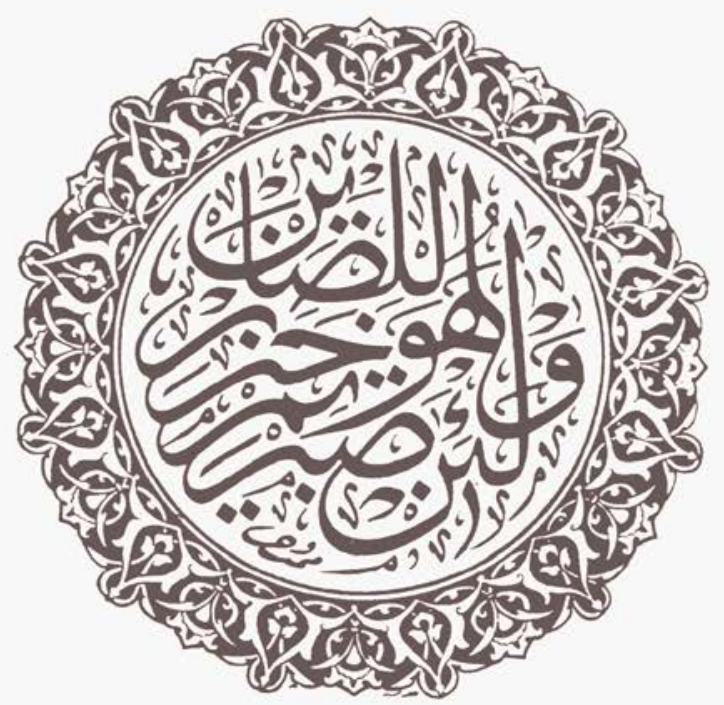

The Economist, March 13, 1982, p. 52. 